\title{
Antibacterial activity of ethanol extract of the defatted seed and seed coat of Moringa oleifera
}

\author{
Philip C. N. Alikwe, ${ }^{1}$ Elijah I. Ohimain ${ }^{2},{ }^{*}$ Douye V. Zige ${ }^{2}$ and \\ Tariwari N.C. Angaye ${ }^{2}$ \\ ${ }^{I}$ Animal Science Department, Niger Delta University, Wilberforce Island, PMB 071 Yenagoa, Bayelsa State \\ ${ }^{2}$ Public Health and Medical Microbiology Research Unit \\ Department of Biological Sciences, Niger Delta University, Wilberforce Island, Bayelsa State Nigeria
}

\begin{abstract}
Recent interest in infectious disease threats to clinical microbiology and public health is the emergence of pathogens with high multidrug resistance especially to available newer broad spectrum antibiotics that is cost prohibitive and are not even within the reach of the poor, making infectious diseases a global burden and therefore prompting the need for the search of potential plants in the treatment of diseases. However antibacterial activity of ethanol extract of Moringa oleifera defatted seed (MODS) and seed coat (MOSC) was conducted. Paper disc diffusion method was used to assess the effect of the extracts on Pseudomonas aerogenosa, Escherichia coli, Klebsiella sp. Salmonella Typhi, Proteus mirabilis, all the examined extract showed varying degrees of antibacterial activities against the selected pathogens. Highest inhibitory effect was observed in Proteus mirabilis $(19 \mathrm{~mm})$ following Salmonella Typhi (16mm) with the Moringa oleifera seed extract, these strains S. Typhi and Proteus mirabilis were resistant to ethanol extract of Moringa oleifera seed coat along with their respective minimum inhibitory concentration (MIC) values ranging from extract on the test isolates ranges from a $0.1 \mathrm{mg} / \mathrm{ml}-100 \mathrm{mg} / \mathrm{ml}$ concentration. This study has shown that the ethanol extract of Moringa oleifera seed possess some degree of antimicrobial activity than ethanol extract of the seed coat and could be a valuable Drug in the treatment of infections caused by the test organisms especially at high dose, therefore these findings support the traditional use of the plant in the treatment of different infections in the area.
\end{abstract}

Key words: Moringa oleifera, Test Organisms, Antibacterial Activity, Minimal Inhibitory Concentration (MIC)

\section{INTRODUCTION}

Bacterial infections are widespread throughout the world, especially in developing countries where in most cases lack of good sanitary practices are seen and primary health care programs are expensive making the fight against diseases difficult (Abdulmoneim and Zaid, 2011). For many years, medicine had depended exclusively on leaves, flowers and barks of plants. Only recently have synthetic drugs come into use and in many instances, these are replica of chemicals identified in plants. According to World Health Organisation, a medicinal plant is any plant which in one or more of its organs, contains substances that can be used for therapeutic purposes or which are precursors for the synthesis of useful drugs (Junaid et al, 2006). However antibacterial compounds has been studied and identified worldwide in several medicinal plants, which are important weapons in the fight against bacterial infections and have contributed greatly to the quality of human life since their introduction (Ali-Shtayeh et al, 1997). Many of the currently used antibacterials are associated with adverse effects such as toxicity, hypersensitivity, immunosuppression, and tissue residues posing public health menace (Gayatri et al, 2010). Also, the newer broad spectrum antibiotics are expensive. These disadvantages undermine the therapeutic utility of the currently available antibacterials and thus necessitating the need for finding alternative remedies for treatment of bacterial diseases (Gayatri et al, 2010). Innumerable antibacterial agents are currently employed in treating bacterial infections. However, the indiscriminate use of antibacterial agents have resulted in the spread of many virulent pathogenic and drug resistant bacterial species (Berkowitz, 1995). Prompting the need for safer and better therapy from medicinal plants.

Moringa oleifera is a well-documented world renowned plant herb known for its extraordinary nutritional and medicinal properties. It is a known antihelmintic, antibiotic, detoxifier and an outstanding immune builder used in many countries to treat malnutrition and malaria. It is also used in water purification and therefore helps in reducing the incidence of water borne diseases (Thilza et al, 2010). The plant Moringa oleifera is a highly valued plant, distributed in many countries of the tropics and subtropics. It is a small or medium sized tree, about $10 \mathrm{~m}$ in height with open crown of drooping fragile branches, feathery foliage of innate leaves and thick corky, whitish bark (Trapti et al, 2009; Roloff, 2009). The plant is variously called horseradish tree, drumstick tree, ben oil tree, miracle tree, and "Mothers best friend" (Julia, 2008). over the years significant work has demonstrated pharmacological actions of the leaves and seeds of Moringa oleifera but only limited work has been reported so far on antibacterial activity of Moringa oleifera defatted (MOD) seed and seed coat 
(MOSC) on Proteus mirabilis, E. coli, Salmonella Typhi, Pseudomonas mirabilis, Klebsiella spp, even with reports of its high medicinal properties. Therefore, it was considered commendable to investigate the antibacterial activity of Moringa oleifera seed (MODS) and seed coat on diarrhoegenic pathogens which are considered global threat to public health.

\section{COLLECTION OF PLANT MATERIAL}

\section{MATERIALS AND METHOD}

Powder from seed and seed coat of Moringa oleifera were obtained from Biu in Borno State from a Moringa seed oil processor through the Department of Animal Science, Faculty of Agriculture, Niger Delta University, Wilberforce Island, Bayelsa State Nigeria.

\section{PREPARATION OF EXTRACT}

\section{Ethanol Extract Preparation}

One hundred (100) grams of the powder for both the seed and seed coat was weighed separately using Satoric AG Gottingen Electronic weighing balance. The weighed samples were soaked in 200mls of ethanol ( $99.9 \%$ concentration) contained in a conical flask. The mixture was swirled. After $72 \mathrm{~h}$ with interval stirring, the mixture was filtered using Whatman no.1 filter paper (Azoro, 2002) into a clean beaker and concentrated to dryness using a rotary evaporator at $70^{\circ} \mathrm{C}$. Extracts was stored in the refrigerator at $8^{\circ} \mathrm{C}$ for use.

\section{TEST BACTERIAL ISOLATES}

The test organism used in this study are strains of Proteus mirabilis, E coli, Salmonella Typhi, Pseudomonas auriginosa, Proteus mirabilis, isolated from stool samples of patient presenting with abdominal distress in Federal Medical Centre Yenagoa Bayelsa State Nigeria, cultured and identified using routine laboratory procedures as described by Cheesebrough (2000).

\section{ANTIBACTERIAL ACTIVITY TESTING FOR PLANT EXTRACTS}

Sensitivity of the pure culture of bacteria isolates to ethanol extracts were determined using agar well diffusion method as reported by Kigigha and Atuzie (2012). Whatman No.1 filter paper was used. The filter paper was cut into circular disc using a perforator giving a diameter of $6 \mathrm{~mm}$. The disc was autoclaved at $121^{\circ} \mathrm{C}$ for $20 \mathrm{~min}$ so as to denature and destroy completely the entire chemical used in its preservation as well as making it sterile before imbedding the extracts. The disc was dipped into the plant extract using a sterile forcep for $15 \mathrm{sec}$ and transferred aseptically into a sterile glass Petri dish and kept in the oven at $55^{\circ} \mathrm{C}$ until the following day.

The test organism were pre-adjusted to the 0.5 McFarland's turbidity standard in a test tube, dipped with a sterile swab stick and used to seed on a solidified oxoid sensitest agar in an inoculating chamber already set aseptically. The prepared disc was carefully transferred onto the inoculated culture plates using sterile forceps. The plates were incubated for $24 \mathrm{~h}$ at $37^{\circ} \mathrm{C}$, after which the zone of inhibition was measured and recorded.

\section{MINIMAL INHIBITORY CONCENTRATION}

The minimum inhibitory concentration is the concentration giving the least inhibitory activity and below which there is no further inhibition. It is therefore regarded as the concentration giving the lowest possible zones of inhibition. Two fold serial dilutions were prepared to obtain a $0.1-100 \mathrm{mg} / \mathrm{ml}$ concentration range. Sterile discs were immersed into the different dilutions and absorption was allowed for 30 minutes. A pair of sterile forceps was used to pick the paper discs and placed on the inoculated plates and the portions were labelled. The plates were incubated at $37^{\circ} \mathrm{C}$ for $24 \mathrm{~h}$ and observed for zone of inhibition.

\section{RESULT}

The antibacterial activity of ethanolic extracts of Moringa oleifera defatted seed (MOD) and seed coat (MOSC) was investigated using agar disc diffusion method, against the selected diarrhoegenic pathogens such as Escherichia Coli, Proteus mirabilis, Klebsiella spp, Pseudomonas aeroginosa and Salmonella Typhi isolated from diarrhoeal cases. The extracts showed varying degrees of antibacterial activities against the selected pathogens. Table 1 shows that the highest inhibitory effect was observed in Proteus mirabilis (19mm) followed by Salmonella Typhi $(16 \mathrm{~mm})$ with the Moringa oleifera seed extract. Some strains (S. Typhi and Proteus mirabilis) were resistant to ethanolic extracts of Moringa oleifera seed coat (Table 1). The seed extracts had activity against Klebsiella $(4 \mathrm{~mm}), P$. aeruginosa $(3 \mathrm{~mm})$ and $E$. coli $(5 \mathrm{~mm})$. The seed coat extract was sensitive to Klebsiella spp (4mm), P. aeruginosa $(4 \mathrm{~mm})$ and E. coli $(2 \mathrm{~mm})$. 
Table 1: In vitro antibacterial effect of ethanolic extract of Moringa oleifera seed and seed coat on test isolates

\begin{tabular}{|l|l|l|l|l|l|}
\hline Antibiotics/extracts & S. Typhi & $\begin{array}{l}\text { Proteus } \\
\text { mirabilis }\end{array}$ & P. auroginosa & E coli & Klebsiella spp \\
\hline Moringa oleifera seed extract & $9 \mathrm{~mm}$ & $16 \mathrm{~mm}$ & $3 \mathrm{~mm}$ & $5 \mathrm{~mm}$ & $4 \mathrm{~mm}$ \\
\hline Moringa oleifera seed coat extract & $\mathrm{R}$ & $\mathrm{R}$ & $4 \mathrm{~mm}$ & $2 \mathrm{~mm}$ & $4 \mathrm{~mm}$ \\
\hline Gentamicin (10ug) & $18 \mathrm{~mm}$ & $21 \mathrm{~mm}$ & $20 \mathrm{~mm}$ & $17 \mathrm{~mm}$ & $16 \mathrm{~mm}$ \\
\hline Blank & $\mathrm{R}$ & $\mathrm{R}$ & $\mathrm{R}$ & $\mathrm{R}$ & $\mathrm{R}$ \\
\hline
\end{tabular}

R- Resistance

Table 2 shows the result of lowest possible inhibition of Moringa oleifera seed extract on the test isolates on a $0.1 \mathrm{mg} / \mathrm{ml}-100 \mathrm{mg} / \mathrm{ml}$ concentration. The results shows that Moringa oleifera seed extract was sensitive to Proteus mirabilis $(5 \mathrm{~mm})$, Salmonella Typhi $(1.7 \mathrm{~mm})$ while Pseudomonas aeroginosa was resistant at $50 \mathrm{mg} / \mathrm{ml}$, Klebsiella spp, and E. coli were resistant at $25 \mathrm{mg} / \mathrm{ml}$ and $75 \mathrm{mg} / \mathrm{ml}$ respectively.

Table 2

The minimum inhibitory concentration for Moringa oleifera seed extract

\begin{tabular}{|l|l|l|l|l|l|}
\hline Extract /concentration & S.Typhi & P. mirabilis & P. auroginosa & E. coli & Klebsiella spp \\
\hline $0.1 \mathrm{mg} / \mathrm{ml}$ & $1.7 \mathrm{~mm}$ & $5 \mathrm{~mm}$ & $\mathrm{R}$ & $\mathrm{R}$ & $\mathrm{R}$ \\
\hline $25 \mathrm{mg} / \mathrm{ml}$ & $3.2 \mathrm{~mm}$ & $7 \mathrm{~mm}$ & $\mathrm{R}$ & $\mathrm{R}$ & $\mathrm{R}$ \\
\hline $50 \mathrm{mg} / \mathrm{ml}$ & $3.2 \mathrm{~mm}$ & $9 \mathrm{~mm}$ & $\mathrm{R}$ & $1 \mathrm{~mm}$ & $\mathrm{R}$ \\
\hline $75 \mathrm{mg} / \mathrm{ml}$ & $3.4 \mathrm{~mm}$ & $13 \mathrm{~mm}$ & $1 \mathrm{~mm}$ & $1.7 \mathrm{~mm}$ & $1.4 \mathrm{~mm}$ \\
\hline $100 \mathrm{mg} / \mathrm{ml}$ & $7.6 \mathrm{~mm}$ & $13.8 \mathrm{~mm}$ & $3 \mathrm{~mm}$ & $4 \mathrm{~mm}$ & $3 \mathrm{~mm}$ \\
\hline
\end{tabular}

R-Resistance

Table 3, shows that at all the concentration of seed seed coat extract used in this experiment had no activity against $S$. Typhi, Proteus mirabilis, and E. coli but was sensitive against $P$. auroginosa and klebsiella spp at 0.1 $\mathrm{mg} / \mathrm{ml}$ concentration.

Table 3

The minimum inhibitory concentration for Moringa oleifera seed coat extract

\begin{tabular}{|l|l|l|l|l|l|}
\hline Extract /concentration & S. Typhi & P. mirabilis & P. auroginosa & E. coli & Klebsiella Spp \\
\hline $0.1 \mathrm{mg} / \mathrm{ml}$ & $\mathrm{R}$ & $\mathrm{R}$ & $1 \mathrm{~mm}$ & $\mathrm{R}$ & $1 \mathrm{~mm}$ \\
\hline $25 \mathrm{mg} / \mathrm{ml}$ & $\mathrm{R}$ & $\mathrm{R}$ & $1.4 \mathrm{~mm}$ & $\mathrm{R}$ & $1.6 \mathrm{~mm}$ \\
\hline $50 \mathrm{mg} / \mathrm{ml}$ & $\mathrm{R}$ & $\mathrm{R}$ & $3 \mathrm{~mm}$ & $\mathrm{R}$ & $\mathrm{R}$ \\
\hline $75 \mathrm{mg} / \mathrm{ml}$ & $\mathrm{R}$ & $\mathrm{R}$ & $\mathrm{R}$ & $\mathrm{R}$ & $\mathrm{R}$ \\
\hline $100 \mathrm{mg} / \mathrm{ml}$ & $\mathrm{R}$ & $\mathrm{R}$ & $\mathrm{R}$ & $\mathrm{R}$ & $\mathrm{R}$ \\
\hline
\end{tabular}

R-Resistance

\section{DISCUSSION}

The growing incidence of multidrug resistance of microorganisms to conventional antimicrobial agents is a source of concern to clinical microbiologists globally. As a result, efforts are being made to develop antimicrobial agents from local sources for better chemotherapeutic effects. The demand for more natural antimicrobials has driven scientists to examine the effectiveness of inhibitory compounds such as extracts from plants (Nasar-Abbas and Halkman, 2004.) several publications have documented plant potential antimicrobial properties (Ahmad and Aqil, 2007). Thus plant extracts are promising natural antimicrobial agents with potential applications in infectious disease for controlling pathogenic bacteria. This study reveals that all the examined extract showed varying degrees of antibacterial activities against the selected pathogens, with higher activity observed in Moringa oleifera seed extract, which is similar with the findings of (Thilza et al, 2010, Jamil et al, 2007; Abdulmoneim et al, 2011). However its activity on Proteus mirabilis and Salmonella Typhi is comparable to some commercial antibiotics. On the other hand these organisms are completely resistant to the seed coat extract in this study and therefore not an alternative therapy on ailment caused by Salmonella and Proteus.

\section{CONCLUSION/SUGGESTION}

In this study, we found out that ethanol extract of seed extracts of $M$. oleifera were active against all the bacteria tested with highest zone of inhibition observed in Proteus mirabilis followed by Salmonella Typhi. Therefore, M. oleifera seed could be a promising antibacterial agent with potential applications in pharmaceutical industry for controlling the pathogenic bacteria. On the other hand, extract from seed coat was less effective. When the obtained results were compared to commercial antibiotics used in the stud, it could be concluded that the ethanol extract of the seeds and seed coat obtained from M. oleifera was less effective than the standard antibiotics used as control. However, efforts should be made to conduct in vivo studies with the extracts on animal model so as to confirm the present in vitro findings as zones of inhibition is not only affected 
by sensitivity of the microorganisms alone but concentration of the extract in the disc used and it's rate of diffusion in the media as well. Testing the toxicity in vivo should also be crucial in determining the optimum dose to be administered as an effective antibiotics.

\section{ACKNOWLEDGEMENT}

The authors wish to thank the Management and staff of Federal Medical Centre, Yenagoa, Bayelsa state for providing the facilities for analysis, also to Agbafor, Sunny Tarila and Owei, Kuronakigha for their support during analysis.

\section{REFERENCES}

[1]. Abdulmoneim, MS, Abu-Zaid IE (2011). An in vitro antimicrobial activity of Moringa oleifera L. seed extracts against different groups of microorganisms Australian Journal of Basic and Applied Sciences, 5(5): 129-134.

[2]. Ahmad, I, Aqil, F (2007). In vitro efficacy of bioactive extracts of 15 medicinal plants against ESâL-producing multidrug-resistant enteric bacteria. Microbiol Res; 162: 264-75.

[3]. Ali-Shtayeh MS, Al-Nuri MA, Yaghmour RM, Faidi YR (1997). Antimicrobial activity of Micromeria nervosa from the Palestinian area. J Ethnopharmacol, 1997, 58(3): 143-147.

[4]. Azoro, C (2000). Antibacterial activity of crude extract of Azadirachita indica on Salmonella typhi. World Journal of Biotechnology, $3: 347-351$

[5]. Berkowitz, FE (1995). Antibiotic resistance in bacteria, South. Med. J . 88,797-804.

[6]. Cheesbrough, M (2000). District laboratory practice in tropical countries. Cambridge University press, United Kingdom. 2:157-199.

[7]. Gayatri, DK. Koley, M. Vadlamudi, VP, Akhilesh, M, Anjana, P and Hirpurkar, DS (2010). (drumstick) root bark. Antibacterial activity of Moringa Oleifera. J. Chem. Pharm. Res, 2(6):424-428

[8]. Jamil, A, Shahid, M, Khan, MM, Ashraf, M (2007). Screening of some medicinal plants for isolation of antifungal proteins and peptides. Pak. J. Bot., 39(1): 211-221.

[9]. Julia, C (2008). A study of nutritional and medicinal values of Moringa oleifera leaves from subsaharan Africa: Ghana, Rwanda Senegal and Zambia. M.S theisis Rutgers, The State University of New Jersey Pp 1

[10]. Junaid, SA, Olabode AO, Onwuliri FC, Okworiu AEJ, Agina SE (2006). The antimicrobial properties of Ocimum gratissimum extracts on some selected bacterial gastrointestinal isolates. Afri. J. Biotechnol. 5 (22): 2315-2321.

[11]. Kigigha, LT, Atuzie, MN (2012). Assessment of traditional medicinal application of Alchornea cordifolia . African Journal of Biotechnology 11(8) 2083-2086

[12]. Nasar-Abbas SM, Halkman AK (2004). Antimicrobial effect of water extract of sumac (Rhus coriaria L.) on the growth of some food borne bacteria including pathogens. Int'1 J Food Microbiol , 97: 63-9.

[13]. Roloff, A, Weisgerber, H, Lang, U, Stimm, B (2009). Moringa oleifera Lam, 1785; Weinheim ISBN: 978-3-527-32141-4.

[14]. Thilza IB, Sanni S, Zakari AI, Sanni, FS, Muhammed T, Musa BJ (2010). In vitro antimicrobial activity of water extract of Moringa oleifera leaf stalk on bacteria normally implicated in eye diseases, Academia arena 2(6):80-82

[15]. Trapti R, Vijay, B, Komal, M, Aswar, PB, Khadabadi SS (2009). Comparative Studies on Anthelmintic Activty of Moringa Oleifera and Vitex Negundo. Asian J. Research Chem. vol. 2(2). 